\title{
WŁAŚCIWOŚĆ ORGANÓW W SPRAWACH O NAKAZANIE USUNIĘCIA ODPADÓW Z MIEJSCA NIEPRZEZNACZONEGO DO ICH SKŁADOWANIA LUB MAGAZYNOWANIA
}

\section{BODIES EMPOWERED TO ISSUE AN INJUNCTION CONCERNING REMOVAL OF ILLEGALLY DISPOSED OR STORED WASTE}

\section{STRESZCZENIE}

Celem opracowania jest analiza zagadnienia, jakim jest właściwość organów w sprawach o nakazanie usunięcia odpadów z miejsca nieprzeznaczonego do ich składowania lub magazynowania. Ustawodawca polski przejawia zauważalną tendencję do stosowania modelu rozproszonej właściwości organów w jednej i tej samej sprawie. Przykładem jest m.in. sprawa nakazania usunięcia odpadów z miejsca

Prof. dr hab., Kierownik Katedry Prawa Ochrony Środowiska WPiA UMK w Toruniu. 
nieprzeznaczonego do ich składowania lub magazynowania, uregulowana w art. 26 ust. 3 ustawy z 2012 roku o odpadach. Właściwość organu w tym zakresie determinowana jest różnymi okolicznościami, nie we wszystkich przypadkach mającymi związek z samą istotą problemu, jaką jest posiadanie odpadów.

\section{Słowa kluczowe}

Prawo o odpadach; składowanie lub magazynowanie odpadów; nakaz.

\section{ABSTRACT}

The aim of the article is to discuss the question of a body empowered to issue an injunction concerning removal of illegally disposed or stored waste. Polish legislator's approach to this problems often involves empowering more than one administrative body to deal with one specific legal case. Article 26(3) of the Waste Law Act of 2012 may be used as an example of such approach. In accordance with this article the empowerment of an administrative body depends on more than one basic factor which is waste possession.

\section{Keywords}

Waste law; waste disposal and storage; injunction.

Coraz częściej w systemie polskiego prawa ochrony środowiska można dostrzec rozproszenie właściwości rzeczowej organów orzekających w sprawach administracyjnych tego samego rodzaju. Jako przykład takiego stanu można chociażby podać art. 90 ustawy z dnia 16 kwietnia 2004 roku o ochronie przyrody $^{1}$, według którego $\mathrm{w}$ sprawach $\mathrm{z}$ zakresu wydawania zezwoleń na usunięcie drzew lub krzewów mogą orzekać: wójt, burmistrz, prezydent miasta, starosta, i wreszcie marszałek województwa ${ }^{2}$. Innym przykładem orzekania w tego samego ro-

1 Tekst jedn. Dz. U. z 2016 r., poz. 2134 ze zm.

2 Bliżej kwestie te i wątpliwości z nimi związane analizują D. Danecka i W. Radecki, Ochrona terenów zieleni i zadrzewień. Art. 78-90 ustawy o ochronie przyrody, Warszawa 2016, s. 254 i n. 
dzaju sprawach administracyjnych jest rozwiązanie przyjęte w art. 26 ustawy z dnia 14 grudnia 2012 roku o odpadach ${ }^{3}$. Według tego przepisu w sprawach o nakazanie usunięcia odpadów z miejsca nieprzeznaczonego do ich składowania lub magazynowania orzekają trzy organy: wójt, burmistrz lub prezydent miasta, starosta i regionalny dyrektor ochrony środowiska.

Rozproszenie właściwości organów, które występuje chociażby w zaprezentowanych powyżej przykładach, ma swoje uzasadnienie w tym, że gmina i jej organy mogą występować w rożnych konfiguracjach podmiotowych.

Z jednej strony organ wykonawczy gminy w osobie wójta, burmistrza lub prezydenta miasta, działający jako organ ochrony środowiska lub ochrony przyrody, podejmuje i dokonuje czynności władczych, orzekając w określonego rodzaju sprawach administracyjnych. Z drugiej jednak strony, gmina występuje w podanych przykładach jako właściciel nieruchomości. Bardzo rozsądnie ustawodawca uznał, że wójt, burmistrz, prezydent miasta nie może orzekać w sprawach, które dotyczą nieruchomości gminy będącej osobą prawną w sytuacji, kiedy organem działającym za osobę prawną jest ten sam wójt, burmistrz, prezydent miasta. Dostrzeżono, iż narusza to zasadę nemo iudex idoneus in causa sua. Zagadnienie rozpraszania właściwości organu w sprawach tego samego rodzaju wymagałoby bliższej analizy naukowej ze szczególnie pogłębionym zbadaniem przyczyn i skutków takich rozwiązań legislacyjnych.

W ramach tego artykułu podejmę analizę jedynie problematyki właściwości organu, kształtowanej w art. 26 ustawy o odpadach. Celem tego artykułu jest zbadanie i wskazanie przesłanek, od których zależy właściwość organu oraz zbadanie mechanizmów i przyczyn przyjętych przez legislatora rozwiązań. Artykuł zakończy ocena stanu de lege lata oraz wnioski de lege ferenda.

Zgodnie z art. 26 ustawy o odpadach „1. Posiadacz odpadów jest obowiązany do niezwłocznego usunięcia odpadów z miejsca nieprzeznaczonego do ich składowania lub magazynowania. 2 . W przypadku nieusunięcia odpadów zgodnie

3 Tekst jedn. Dz. U. z 2016 r., poz. 1987 ze zm. 
z ust. 1, wójt, burmistrz lub prezydent miasta, w drodze decyzji wydawanej z urzędu, nakazuje posiadaczowi odpadów usunięcie odpadów z miejsca nieprzeznaczonego do ich składowania lub magazynowania, z wyjątkiem gdy obowiązek usunięcia odpadów jest skutkiem wydania decyzji o cofnięciu decyzji związanej z gospodarką odpadami. 3. Nakaz usunięcia odpadów, o którym mowa w ust. 2, z terenów zamkniętych oraz z nieruchomości, którymi gmina włada jako władający powierzchnią ziemi, a niebędących $\mathrm{w}$ posiadaniu innego podmiotu - wydaje właściwy regionalny dyrektor ochrony środowiska. 4. Jeżeli posiadacz odpadów nie posiada tytułu prawnego do nieruchomości, z której jest obowiązany usunąć odpady, władający powierzchnią ziemi jest obowiązany umożliwić posiadaczowi odpadów usunięcie odpadów z tej nieruchomości, a w przypadku wykonania zastępczego decyzji - organowi egzekucyjnemu. 5. Władającemu powierzchnią ziemi przysługuje od posiadacza odpadów wynagrodzenie za udostępnienie nieruchomości. 6. W decyzji, o której mowa w ust. 2, określa się w szczególności: 1) termin usunięcia odpadów; 2) rodzaj odpadów; 3) sposób usunięcia odpadów".

Przepis ten jest niezwykle rozbudowany, co zresztą jest zauważalną tendencją w polskim prawie ochrony środowiska.

Składają się na niego liczne elementy rodzące wiele wątpliwości. Podstawowym zagadnieniem, które wyłania się $\mathrm{z}$ art. 26 ustawy o odpadach, jest zagadnienie obowiązku posiadacza odpadów usunięcia ich z miejsca nieprzeznaczonego do składowania lub magazynowania takich odpadów. Aksjologię wyznacza zresztą tytuł rozdziału, w którym ten przepis się znajduje, a mianowicie - „Usuwanie odpadów z miejsca nieprzeznaczonego do ich składowania lub magazynowania”. Problem właściwości organu ma zatem, $\mathrm{w}$ analizowanym przepisie, postać zagadnienia drugorzędnego, choć legislator poświęca tej kwestii bardzo dużo uwagi.

Jak słusznie zauważył W. Radecki, „W realizacji postanowień art. 26 biorą udział trzy podmioty: 1) posiadacz odpadów [...], 2) organ administracji publicznej, tj. wójt, burmistrz lub prezydent miasta albo regionalny dyrektor ochrony środowiska, 4/2016 3) władający powierzchnią ziemi, jeśli nie jest nim posiadacz od- 
padów;[...]"4. Ten trafny podział dokonany przez W. Radeckiego należałoby uzupełnić o wymienienie katalogu organów administracji publicznej, orzekających w sprawach usunięcia odpadów z miejsca, które nie jest przeznaczone do ich składowania lub magazynowania, o starostę. Jednak organ ten, choć jest kompetentny w orzekaniu o usuwaniu odpadów, to nie został wprost wymieniony. Dlatego też, gdyby przyjąć za kryterium wymienienia organów administracji publicznej, kryterium bezpośredniego wskazania takiego organu w art. 26 ustawy o odpadach, to słusznie W. Radecki pominął starostę, przepis ten bowiem wymienia wprost jedynie dwa organy - wójta, burmistrza, prezydenta miasta i regionalnego dyrektora ochrony środowiska.

Trafnie również W. Radecki dostrzegł, iż od strony podmiotowej rzeczywiście norma prawna adresowana jest do trzech podmiotów. Dla dalszej analizy kwestia posiadacza odpadów i władającego powierzchnią ziemi będzie miała znaczenie jedynie dla oceny właściwości regionalnego dyrektora ochrony środowiska.

W teorii postępowania administracyjnego wymienia się trzy podstawowe rodzaje właściwości organów administracji publicznej: właściwość miejscową, właściwość rzeczową oraz właściwość funkcjonalną ${ }^{5}$ Samo pojęcie właściwości organu jest definiowane jako kryteria, według których ustala się, który konkretnie organ administracji publicznej jest uprawniony i jednocześnie zobowiązany do załatwienia określonego typu spraw administracyjnych, a inaczej rzecz ujmując, jako zdolność organu administracji do rozpoznawania i rozstrzygania określonego rodzaju spraw w postępowaniu administracyjnym ${ }^{6}$.

W piśmiennictwie właściwość miejscową określa się jako właściwość organu administracji publicznej ocenianą według siedziby organu i okręgu, podlegającego kognicji tego organu.

4 W. Radecki, Ustawa o odpadach. Komentarz, Warszawa 2013, s. 149-150.

5 Por. chociażby K. Celińska-Grzegorczyk, R. Hauser, W. Sawczyn, A. Skoczylas, Postępowanie administracyjne i sądowoadministracyjne, Warszawa 2011, s. 35.

6 M. Wierzbowski, A. Wiktorowska, w: Postępowanie administracyjne ogólne, podatkowe, egzekucyjne i przed sądami administracyjnymi, M. Wierzbowski (red.), Warszawa 2008, s. 39. 
Inaczej rzecz ujmując, właściwość miejscowa oznacza, który organ będzie właściwy ze względu na swoją siedzibę i ze względu na przedmiot postępowania. Podkreśla się, że jest to zdolność organu administracji publicznej do załatwienia spraw należących do jego właściwości rzeczowej na obszarze określonej jednostki podziału terytorialnego kraju stanowiącym przypisany temu organowi obszar działania ${ }^{7}$.

Artykuł 26 ustawy o odpadach w istocie nie rozstrzyga kwestii właściwości miejscowej organów w nim wymienionych. Ustalanie właściwości miejscowej odbywa się zatem na podstawie przepisów ogólnych. Zgodnie z art. 21§1 pkt 1 ustawy z dnia 14 czerwca 1960 roku Kodeks postępowania administracyjnego ${ }^{8}$, „właściwość miejscową organu administracji publicznej ustala się: [...] w sprawach dotyczących nieruchomości według miejsca jej położenia; jeżeli nieruchomość położona jest na obszarze właściwości dwóch lub więcej organów, orzekanie należy do organu, na którego obszarze znajduje się większa część nieruchomości". Nie ulega wątpliwości, że sprawy związane z usuwaniem odpadów z miejsca nieprzeznaczonego do ich składowania lub magazynowania są sprawą dotyczącą nieruchomości. Argument ten ulega wzmocnieniu, jeśli zwróci się uwagę, że adresatem normy prawnej może być również podmiot władający powierzchnią ziemi. Podmiot ten zdefiniowany jest w art. 3 pkt 44 ustawy z dnia 27 kwietnia 2001 roku Prawo ochrony środowiska ${ }^{9}$ jako „właściciel nieruchomości, a jeżeli w ewidencji gruntów i budynków prowadzonej na podstawie ustawy - Prawo geodezyjne i kartograficzne ujawniono inny podmiot władający gruntem - podmiot ujawniony jako władający". Organem właściwym miejscowo będzie zatem ten organ, w obszarze działalności którego, nieruchomość lub jej większa część jest położona. W praktyce wyznaczenie właściwości miejscowej nie budzi istotnych problemów.

7 H. Knysiak-Molczyk, w: Postępowanie administracyjne, T. Woś (red.), Warszawa 2015, s. 140.

8 Tekst jedn. Dz. U. z 2016 r., poz. 23 ze zm.; dalej cyt.: k.p.a.

9 Tekst jedn. Dz. U. z 2016 r., poz. 672 ze zm.; dalej cyt.: u.p.o.ś. 
Drugim rodzajem właściwości jest właściwość rzeczowa. Zgodnie z art. 20 k.p.a. „właściwość rzeczową organu administracji publicznej ustala się według przepisów o zakresie jego działania". Właściwość rzeczowa organu orzekającego o obowiązku usunięcia odpadów z miejsca nieprzeznaczonego do ich magazynowania lub składowania rozkłada się na cztery organy, choć sam art. 26 ustawy o odpadach wymienia tylko dwa.

Jak wynika z ust. 2 art. 26 ustawy o odpadach, organem rzeczowo właściwym co do zasady jest: wójt, burmistrz, prezydent miasta. Właściwość rzeczowa tego organu nie jest niczym zdeterminowana i nie zależy od jakichkolwiek okoliczności. Trafnie zauważa B. Adamiak, iż „podstawą ustalenia właściwości rzeczowej organów administracji publicznej, należących do systemu organów wyposażonych w kompetencję ogólną do prowadzenia postępowania administracyjnego, są przepisy ustaw materialnoprawnych"10.

Organ ten orzeka, co do zasady, w każdej sytuacji, w której wystąpią przesłanki nakazujące usunąć odpady z miejsca nieprzeznaczonego do ich składowania lub magazynowania. Można zatem przyjąć, że wójt, burmistrz, prezydent miasta jest organem ogólnej właściwości rzeczowej w sprawach o nakazanie usunięcia odpadów z miejsc nieprzeznaczonych do ich składowania lub magazynowania. Od tej zasady ustawodawca przewidział dwa wyjątki, przy czym każdy z nich wynika z innych okoliczności.

Pierwszy z tych wyjątków został dokładnie określony w art. 26 ust. 2 ustawy o odpadach. Zresztą sam ustawodawca, użył sformułowania „Z wyjątkiem”, co oznacza uchylenie ogólnej właściwości rzeczowej.

Wójt, burmistrz, prezydent miasta nie będzie orzekał w sprawie o nakazanie nieusunięcia odpadów z miejsca nieprzeznaczonego do ich składowania lub magazynowania, jeżeli obowiązek usunięcia tych odpadów jest skutkiem wydania decyzji o cofnięciu decyzji związanej z gospodarką odpadami.

10 B. Adamiak, w: B. Adamiak, J. Borkowski, A. Skoczylas, Prawo procesowe administracyjne, System Prawa Administracyjnego - t. 9, R. Hauser, Z. Niewiadomski, A. Wróbel (red.),Warszawa 2010, s. 106. 
U podstaw tego rozwiązania legło założenie, aby nie dochodziło do sytuacji dublowania orzeczeń, nakazujących $\mathrm{w}$ istocie dokładnie to samo zachowanie. Obowiązek usunięcia odpadów z miejsca nieprzeznaczonego do ich składowania lub magazynowania może być skutkiem różnych okoliczności. W art. 26 ust. 2 ustawy o odpadach, legislator przewidział dwie grupy takich przyczyn, które mogą powodować skutek w postaci obowiązku usunięcia odpadów.

Pierwsza z tych przyczyn wystąpi wtedy, gdy odpady zostaną umieszczone $\mathrm{w}$ miejscu, które nigdy nie było przeznaczone do składowania lub magazynowania odpadów. Druga z przyczyn wystąpi wtedy, gdy określone miejsce było wprawdzie przewidziane do składowania lub magazynowania odpadów, ale możliwość ta odpadła. Przy czym powodem odpadnięcia możliwości składowania lub magazynowania odpadów jest wyłącznie cofnięcie decyzji związanej z gospodarką odpadami. W tym kontekście znaczenia nabiera pojęcie „decyzja związana z gospodarką odpadami", gdyż jej cofnięcie skutkuje obowiązkiem usunięcia odpadów. Wojciech Radecki wskazuje, że chodzi tutaj o sytuacje określone w art. 47 ust. 5 ustawy o odpadach, zgodnie z którym „posiadacz odpadów, któremu cofnięto zezwolenie, jest obowiązany do usunięcia odpadów i skutków prowadzonej działalności, objętej tym zezwoleniem, na własny koszt [...]". Dalej Autor ten wskazuje, iż w takiej sytuacji stosuje się odpowiednio art. 26 ust, 4 i 5 ustawy o odpadach, wobec czego nie ma potrzeby wydawania odrębnej decyzji nakazującej usunięcie odpadów ${ }^{11}$.

Jednak pojęcie „decyzja związana z gospodarką odpadami" musi być rozumiana szerzej, niż tylko w kontekście art. 47 ust. 5. Artykuł 47 ust. 5 ustawy o odpadach dotyczy tylko sytuacji, gdy cofnięto zezwolenie na zbieranie odpadów lub zezwolenie na przetwarzanie odpadów. W przepisie tym bowiem ustawodawca wyraźnie wskazuje na okoliczność cofnięcia zezwolenia. Gdyby zakres art. 26 ust. 2 ustawy o odpadach był tożsamy z zakresem art. 47 ust. 5, to ustawodawca dałby temu

11 W. Radecki, Ustawa o..., s. 151. 
wyraz, wskazując na cofnięcie zezwolenia, a nie cofnięcie decyzji związanej z gospodarką odpadami.

Ustawodawca nie wskazuje dokładnie, na jakiś konkretny rodzaj decyzji. Podaje jedynie, że musi istnieć związek między tą decyzją a gospodarką odpadami. Bez wątpienia związek ten występuje w art. 47 ust. 5 ustawy o odpadach, ale nie wyczerpuje to sytuacji objętych dyspozycją art. 26 ust. 2 ustawy o odpadach. Można tutaj również wskazać na decyzje dotyczące już stricte składowania odpadów czy wręcz samego składowiska odpadów (np. pozwolenie na budowę). Przepis ten obejmuje zresztą nie tylko decyzje wydawane na podstawie ustawy o odpadach, ale każdą decyzję powiązaną z gospodarką odpadami.

Drugi wyjątek od zasady, jaką jest właściwość rzeczowa wójta, burmistrza, prezydenta miasta przewidziany jest w art. 26 ust. 3. Przepis ten określa, w jakich wyjątkowych sytuacjach organem właściwym do wydania decyzji nakazującej jest regionalny dyrektor ochrony środowiska. Właściwość regionalnego dyrektora ochrony środowiska, jako organu wydającego decyzję nakazującą usunięcie odpadów, zdeterminowana jest dwoma okolicznościami. Organ ten orzeka, jeśli usunięcie odpadów ma nastąpić z terenu zamkniętego. Sam prawodawca w art. 3 pkt 40 u.p.o.ś. definiuje co to jest teren zamknięty. Przepis ten stanowi, iż „ilekroć w ustawie jest mowa o: [...] terenie zamkniętym - rozumie się przez to teren, a w szczególnych przypadkach obiekt budowlany lub jego część, dostępny wyłącznie dla osób uprawnionych oraz wyznaczony w sposób określony w ustawie z dnia 17 maja 1989 roku - Prawo geodezyjne i kartograficzne". W praktyce właściwość rzeczowa regionalnego dyrektora ochrony środowiska, wynikająca z okoliczności, iż doszło do składowania lub magazynowania odpadów w miejscu do tego nieprzeznaczonym, a zlokalizowanym na terenie zamkniętym, nie budzi poważniejszych wątpliwości.

Problem może powstać w sytuacji, gdy odpady są magazynowane lub składowane w miejscach nieprzeznaczonych do ich składowania lub magazynowania, które częściowo są położone na terenie zamkniętym, a częściowo poza terenem zamkniętym. Chodzi o sytuację, gdy do składowania lub magazynowania odpadów dochodzi na granicy pomiędzy terenem zamkniętym i te- 
renem, który już nie ma charakteru terenu zamkniętego. Ustawodawca w żaden sposób nie rozstrzyga problemu właściwości organu w takiej sytuacji.

Nie będzie tutaj miała zastosowania ogólna reguła określona w k.p.a., która była już wskazywana powyżej, iż właściwym miejscowo organem jest ten organ, na którego obszarze znajduje się większa część nieruchomości. Reguła ta odnosi się bowiem tylko do sytuacji, gdy większa część nieruchomości znajduje się na obszarze działania określonego organu. Natomiast przepis ten nie dotyczy sytuacji, gdy składowanie lub magazynowanie odpadów odbywa się w ten sposób, że ich większa część znajduje się na obszarze działania jednego organu, a mniejsza część na obszarze działania innego organu. Istotne jest również to, że ta reguła dotyczy tylko właściwości miejscowej, a więc właściwości determinującej jurysdykcję organu tego samego rodzaju stopnia i szczebla. Tymczasem w analizowanej sytuacji magazynowanie lub składowanie odpadów na terenie zamkniętym lub poza terenem zamkniętym determinuje właściwość rzeczową organu. Ten sam problem może również wystąpić w przypadku ogólnej właściwości rzeczowej wójta, burmistrza, lub prezydenta. Możliwa jest bowiem sytuacja, iż odpady są składowane na nieruchomości lub nieruchomościach położonych na granicy gmin.

Wobec braku przepisów szczególnych, według których kształtowano by właściwość jednego tylko organu, zastosowanie znajdą ogólne reguły określania właściwości organu, a więc miejsca posadowienia odpadów. We wskazanych wyżej granicznych przypadkach, do granicy z terenem zamkniętym będzie orzekał wójt, burmistrz, prezydent miasta, a w odniesieniu do terenu zamkniętego będzie orzekał regionalny dyrektor ochrony środowiska. Nie inaczej będzie się kształtowała właściwość miejscowa w przypadku magazynowania lub składowania odpadów na granicy gmin. Każdy z wójtów, burmistrzów lub prezydentów będzie orzekał o obowiązku usunięcia odpadów w odniesieniu do obszaru swojej gminy.

Jednak art. 26 ust. 3 ustawy o odpadach określa również drugą okoliczność, która determinuje właściwość rzeczową regionalnego dyrektora ochrony środowiska. Regionalny dyrektor ochrony środowiska wydaje nakaz usunięcia odpadów z nieru- 
chomości, którymi gmina włada jako władający powierzchnią ziemi, a nie będących $\mathrm{w}$ posiadaniu innego podmiotu. Właściwość rzeczowa regionalnego dyrektora ochrony środowiska uzależniona jest od jednej przesłanki pozytywnej i jednej przesłanki negatywnej. Przesłanką pozytywną determinującą właściwość regionalnego dyrektora ochrony środowiska jest to, że odpady były składowane lub magazynowane na nieruchomości, którymi gmina włada jako władający powierzchnią ziemi. Pojęcie nieruchomości należy definiować tak jak to wynika z art. 46 k.c. ${ }^{12}$, który stanowi, iż „nieruchomościami są części powierzchni ziemskiej stanowiące odrębny przedmiot własności (grunty), jak również budynki trwale z gruntem związane lub części takich budynków, jeżeli na mocy przepisów szczególnych stanowią odrębny od gruntu przedmiot własności". W art. 26 ust. 3 pojawiają się jednak w odniesieniu do nieruchomości pojęcia charakterystyczne dla prawa ochrony środowiska, a mianowicie pojęcie władający powierzchnią ziemi i powierzchnia ziemi. Oba te pojęcie zdefiniowane są w art. 3 pkt 25 i 44 u.p.o.ś., który stanowi, iż „ilekroć w ustawie jest mowa o: 25) powierzchni ziemi - rozumie się przez to ukształtowanie terenu, glebę, ziemię oraz wody gruntowe, z tym że: a) gleba - oznacza górną warstwę litosfery, złożoną z części mineralnych, materii organicznej, wody glebowej, powietrza glebowego i organizmów, obejmującą wierzchnią warstwę gleby i podglebie, b) ziemia oznacza górną warstwę litosfery, znajdującą się poniżej gleby, do głębokości oddziaływania człowieka, c) wody gruntowe - oznaczają wody podziemne w rozumieniu art. 9 ust. 1 pkt 22 ustawy z dnia 18 lipca 2001 roku - Prawo wodne (Dz. U. z 2012 roku poz. 145 , z późn. zm.), które znajdują się w strefie nasycenia i pozostają w bezpośredniej styczności z gruntem lub podglebiem [...]; 44) władającym powierzchnią ziemi - rozumie się przez to właściciela nieruchomości, a jeżeli w ewidencji gruntów i budynków prowadzonej na podstawie ustawy - Prawo geodezyjne i kartograficzne ujawniono inny podmiot władający gruntem - podmiot ujawniony jako władający".

12 Ustawa z dnia 23 kwietnia 1964 roku Kodeks cywilny, tekst jedn. Dz. U. z 2016 r., poz. 380 ze zm.; dalej cyt.: k.c. 
Legislator słusznie połączył problem nieruchomości z kategoriami pojęciowymi, którymi posługuje się w ustawie Prawo ochrony środowiska, gdyż w ten sposób zachował spójność terminologiczną i konstrukcyjną całego prawa ochrony środowiska. Przesłanką negatywną jest okoliczność, iż gmina nie może być posiadaczem. Jednak ocena tej przesłanki negatywnej, od której zależy właściwość rzeczowa regionalnego dyrektora ochrony środowiska, nasuwa pewne wątpliwości, czy sformułowanie „niebędące w posiadania gminy”, odnosi się do odpadów czy też - do nieruchomości. Kryteria językowej oceny normy prawnej zawodzą, $\mathrm{w}$ tym przypadku albowiem sformułowanie „niebędących w posiadaniu” zostało użyte w liczbie mnogiej. W art. 26 ust. 3 ustawy o odpadach w liczbie mnogiej użyto również pojęcia odpady i nieruchomości. Zatem „niebędących w posiadaniu" może odnosić się według kryteriów językowych zarówno do odpadów, jak i do nieruchomości. Wątpliwość ta wzmocniona jest również poprzez argument, iż zarówno odpady mogą być przedmiotem posiadania, ale i nieruchomości mogą być przedmiotem posiadania.

W piśmiennictwie problem ten nie został dostrzeżony, choć zaproponowano określony sposób rozumienia tego przepisu. A. Mostowska, Ł. Budziński i J. Wilczyńska wskazują, iż regionalny dyrektor ochrony środowiska jest właściwy do nakazania usunięcia odpadów z nieruchomości, którymi gmina włada jako władającym powierzchnią ziemi, a jej posiadaczem nie jest inny podmiot ${ }^{13}$. Do identycznego wniosku dochodzi A. Pacek-Łopalewska, która również posiadanie wiąże nie z odpadami, ale z nieruchomością gminy ${ }^{14}$. Kwestii tej w ogóle nie analizuje Z. Bukowski, który poprzestaje jedynie na wskazaniu reguł obowiązku usunięcia odpadów ${ }^{15}$.

13 Ustawa o odpadach. Komentarz, A. Mostowska (red.), Warszawa 2014, s. 87.

14 A. Pacek-Łopalewska, Ustawa o odpadach. Komentarz, Wrocław 2013, s. 118.

15 Z. Bukowski, Prawo gospodarki odpadami, Poznań 2014, s. 69. W tym przypadku jednak pominięcie kwestii właściwości organów tłumaczy charakter opracowania. 
Na tle art. 26 ust. 3 ustawy o odpadach są zatem możliwe cztery sytuacje, gdy gmina jest władającym powierzchnią ziemi. Pierwsza z nich wystąpi, gdy gmina jest władającym powierzchnią ziemi i jednocześnie, biorąc pod uwagę domniemanie, iż ów władający jest też posiadaczem odpadów, będzie posiadaczem odpadów. Druga sytuacja wystąpi, gdy gmina jest władającym powierzchnią ziemi, ale nie jest posiadaczem odpadów ${ }^{16}$. Trzecia sytuacja jest możliwa, gdy gmina jest władającym powierzchnią ziemi, ale nie jest jej posiadaczem, a na nieruchomości znajdują się odpady ${ }^{17}$. Czwarta sytuacja wystąpi wtedy, gdy gmina jest władającym powierzchnią ziemi, a posiadacz nieruchomości, inny niż gmina, jest jednocześnie posiadaczem odpadów.

Biorąc pod uwagę dominujący pogląd w doktrynie, regionalny dyrektor ochrony środowiska orzekałby jedynie w sytuacji trzeciej i czwartej, gdyż tylko w tych dwóch przypadkach posiadanie nieruchomości jest oderwane od gminy, a posiadaczem tejże nieruchomości jest inny podmiot.

Natomiast w przypadku pierwszym wójt, burmistrz i prezydent miasta orzekałby w swojej własnej sprawie, nakazując gminie usunięcie odpadów. W przypadku drugim wprawdzie wójt, burmistrz, prezydent miasta musiałby wszcząć postępowanie przeciwko jednostce samorządu terytorialnego, której jest organem, ale jednocześnie jako organ osoby prawnej wzruszyłby w postępowaniu przed sobą prowadzonym domniemanie, iż reprezentowana przez niego gmina, pomimo iż jest władającym powierzchnią ziemi, nie jest posiadaczem odpadów. Należy przy tym zaznaczyć, iż w orzecznictwie przyjęto, że postępowanie o nakazanie usunięcia odpadów wszczyna się jedynie z urzędu. Wojewódzki Sąd Administracyjny w Gdańsku w wyroku z dnia 1 października 2014 w sprawie sygn. II SA/Gd 300/14 (LEX nr 1534081), wskazał, iż „1. Podstawą ustaleń w zakresie rodzaju odpadów nie mogą być jedynie dokumenty wytworzone przez stronę postępowania lub podmioty działające na jej zlecenie.

16 Inaczej rzecz ujmując, wzruszyła domniemanie, iż władający powierzchnią ziemi jest jednocześnie posiadaczem odpadów.

$17 \mathrm{~W}$ tej sytuacji zastosowanie będzie miało domniemanie, iż władający powierzchnią ziemi jest jednocześnie posiadaczem odpadów. 
Podstawą ustaleń w tym zakresie winien być przede wszystkim przeprowadzony przez organ dowód z oględzin odpadów i nieruchomości, na której się znajdują. 2. Decyzja w przedmiocie nakazania usunięcia odpadów z miejsc nieprzeznaczonych do ich składowania lub magazynowania jest wydawana $\mathrm{z}$ urzędu. Postępowanie $\mathrm{w}$ tym przedmiocie może zatem zostać wszczęte wyłącznie z urzędu, natomiast nie może być w ogóle wszczęte na wniosek". Po skutecznym, bez wątpienia, domniemaniu orzekłby o nakazaniu usunięcia odpadów z nieruchomości gminy przez ich posiadacza, którym z całą pewnością nie byłaby gmina. Ta bowiem skutecznie wzruszy domniemanie w postępowaniu prowadzonym przez jej organ wykonawczy.

Rozważyć można te same sytuacje przy przyjęciu założenia, iż kwestia posiadania odnosi się nie do nieruchomości, ale do odpadów. W takiej sytuacji w każdym przypadku orzekałby regionalny dyrektor ochrony środowiska. W pierwszym przypadku nakazywałby gminie usunięcie odpadów, biorąc pod uwagę domniemanie, iż władający powierzchnią ziemi jest jednocześnie posiadaczem odpadów. W drugim przypadku wprawdzie regionalny dyrektor ochrony środowiska wszczynałby postępowanie przeciwko gminie, ale ta $\mathrm{w}$ drodze przeciwdowodu wykazałaby, kto jest posiadaczem odpadów.

W trzeciej sytuacji posiadanie nieruchomości przez inny podmiot nie miałoby jakiegokolwiek znaczenia, gdyż postępowanie byłoby prowadzone przeciwko gminie, jako władającemu powierzchnią ziemi z jednoczesnym powołaniem się na domniemanie. Jest też możliwa sytuacja, iż posiadacz nieruchomości, inny niż gmina, zostanie wskazany w ewidencji gruntów i budynków jako władający. W tej sytuacji wójt, burmistrz, prezydent miasta będzie prowadził postępowanie przeciwko posiadaczowi, będącemu jednocześnie władającym powierzchnią ziemi, z jednoczesnym powołaniem się na domniemanie.

Podobnie należy ocenić sytuację czwartą, gdy posiadacz nieruchomości jest jednocześnie posiadaczem odpadów. W tym wypadku nakaz usunięcia odpadów będzie kierowany do takiego podmiotu nie dlatego, iż jest on posiadaczem nieruchomości, ale dlatego, iż jest on posiadaczem odpadów; wszak o taki podmiot w art. 26 ustawy o odpadach chodzi. Organem właściwym 
byłby więc wójt, burmistrz, prezydent miasta. Adresatem decyzji nakazującej jest bowiem posiadacz odpadów, a nie posiadacz nieruchomości, który może, ale nie musi być jednocześnie posiadaczem odpadów.

Celem rozwiązań przyjętych w art. 26 ust. 3 ustawy o odpadach było zachowanie zasady nemo iudex idoneus in causa sua. Tymczasem przeanalizowane przypadki, przy założeniu, że chodzi o posiadanie nieruchomości, prowadzą do jednoznacznego wniosku, iż zasada ta będzie naruszana. Cel zostanie osiągnięty, jeśli pojęcie posiadania odnieść nie do nieruchomości , a do odpadów. Wtedy, w sytuacjach, gdy gmina jest posiadaczem odpadów, będzie orzekał regionalny dyrektor ochrony środowiska, a gdy posiadaczem odpadów będzie inny podmiot, orzekać będzie wójt, burmistrz, prezydent miasta. Przecież adresatem decyzji nakazującej jest posiadacz odpadów.

Reasumując, właściwość organów orzekających na podstawie art. 26 ustawy o odpadach nie jest tak jednoznaczna, jakby się prima facie wydawało. Jest ona determinowana różnymi okolicznościami, mającymi niekoniecznie związek z samą istotą problemu, jaką jest posiadanie odpadów, a nie posiadanie nieruchomości. Zasada, jaką jest właściwość wójta, burmistrza, prezydenta miasta, jest wyłączona w przypadkach określonych w art. 26 ust. 3 ustawy o odpadach. Trzeba pamiętać, iż wyjątki należy interpretować ściśle.

\section{BIBLIOGRAFIA}

Adamiak B., w: B. Adamiak, J. Borkowski, A. Skoczylas, Prawo procesowe administracyjne, System Prawa Administracyjnego - t. 9, R. Hauser, Z. Niewiadomski, A. Wróbel (red.), Warszawa 2010. Bukowski Z., Prawo gospodarki odpadami, Poznań 2014.

Celińska-Grzegorczyk K., Hauser R., Sawczyn W., Skoczylas A., Postępowanie administracyjne i sq̨dowoadministracyjne, Warszawa 2011.

Danecka D., Radecki W., Ochrona terenów zieleni i zadrzewień. Art. 78-90 ustawy o ochronie przyrody, Warszawa 2016. 
Knysiak-Molczyk H., w: Postępowanie administracyjne, T. Woś (red.), Warszawa 2015.

Pacek-Łopalewska A., Ustawa o odpadach. Komentarz, Wrocław 2013. Radecki W., Ustawa o odpadach. Komentarz, Warszawa 2013.

Ustawa o odpadach. Komentarz, A. Mostowska (red.), Warszawa 2014. Wierzbowski M., Wiktorowska A., w: Postępowanie administracyjne ogólne, podatkowe, egzekucyjne i przed sądami administracyjnymi, M. Wierzbowski (red.), Warszawa 2008.

\section{Kontakt e-mail:}

kpos@umk.pl 